\title{
THE EFFECT OF CSR HOTEL DEVELOPMENT ON MICRO BUSINESS POTENTIAL IN ENVIRONMENTAL CONSERVATION
}

\author{
Johny Subarkah $^{1^{*}}$, Ravik Karsidi ${ }^{2}$, Kuncoro Diharjo ${ }^{3}$, Drajat Tri Kartono ${ }^{4}$ \\ ${ }^{1,2,3,4}$ Department of Development Extension / Community Empowerment, Postgraduate Program, \\ Sebelas Maret University, Jl. Ir. Sutami No. 36 Surakarta, 57126, Indonesia \\ ${ }^{1}$ Email: jsubarkah@gmail.com \\ ${ }^{2}$ Email: ravik@uns.ac.id \\ ${ }^{3}$ Email: kuncorodiharjo@ft.uns.ac.id \\ ${ }^{4}$ Email: drajat@uns.ac.id
}

\begin{abstract}
Companies that are engaged in the tourism or hospitality industry sector are also not inferior to implement CSR activities. The development of CSR in the tourism sector, especially hotels, does not run as fast as other business sectors. Social responsibility is an important thing that needs to be considered for the progress of a country and region in particular. The research method used is quantitative. The data used are questionnaires distributed to customers and through direct interviews with farmers micro-entrepreneurs who are partners for Lorin Solo Hotels, Sahid Jaya Solo Hotels and New Kuta Hotels in Bali. The results of the study show that the Development of CSR Hotels has a significant positive effect on the Empowerment of Farmers Micro Enterprises in Environmental Conservation. This means that through the CSR hotel development activities carried out it will have a good effect and make the name of the hotel can be large in the eyes of the wider community and Micro Farmers also become more empowered.
\end{abstract}

Keywords: Development of CSR Hotels, Empowerment of Farmers Micro Enterprises

\section{INTRODUCTION}

The issue of corporate social responsibility has developed very rapidly in line with the development of community empowerment. One of its mandates is that the business world is not merely pursuing profits, but also being ethical to the local community and to the environmental impact of the company's operations. Among the corporate ethics activities that are now developing are community development by means of donations. According to a study conducted by Jung (1994) corporate social responsibility is generally influenced by three important factors, namely (1) the size and maturity of the company on the scale of funding; (2) tax regulations and systems applicable in a country; and (3) the form of ownership and management of the company.

Satisfaction with star-rated hotel services in Indonesia is still different. As for example three-star, four-star and five-star hotels in the Special Region of Yogyakarta have not provided maximum customer satisfaction. This is shown by the higher expectations of customers for personal contacts, supporting physical facilities and equipment than the performance perceived by customers (Maskuri Utomo, 2010).

Surakarta and its surrounding areas have quite a number of star hotels. One star hotels as many as 7 hotels, two star hotels as many as 10 hotels, three star hotels as many as 15 hotels, four star hotels as many as 5 hotels and five star hotels as many as 4 
hotels. Of all the star hotels can accommodate 12,928 guests per day.

The occupancy rate of hotel rooms in Surakarta in 2015 amounted to $39.73 \%$ and in 2016 amounted to $44.11 \%$. From these data it can be seen that occupancy rates in this region are still low. This will also lead to fierce competition among star hotels in Surakarta.

Corporate social responsibility or Corporate Social Responsibility (CSR) itself is a concept that is still an interesting study material among academics and in the business world. This is inseparable from the differences in views between adherents of classical economic theory such as Adam Smith who views that the company is solely tasked with seeking profits. This opinion is also reinforced by Milton Friedman (1962) in his book entitled Capitalism and Freedom, essentially arguing that the only purpose of a company's social responsiveness is to maximize the company's income and wealth for its shareholders.

In the tourism sector, especially the hospitality industry, the development of this concept does not run as fast as in the business sector where business activities manage and utilize natural resources, such as mining. The field of hospitality services when viewed in an explanation Article 74 of the Company Law is not a business activity that utilizes natural resources but can be interpreted as a business activity that has an impact on the function of natural resource capabilities. This seems to make the hotel become not too urgent to implement CSR. If mining companies clearly must implement CSR because they use natural resources as a commodity to be traded. Hotels do not use natural resources as commodities, but have ever realized that hotels use water to run their businesses, even though water is only used as a complementary service for guests who stay overnight.
The number of new hotels that have operated has implications for the ratio between available rooms and guests / tourists who stay unbalanced, thus causing unhealthy price competition. This means that the number of rooms is too much compared to the number of tourists who come and stay in Surakarta City,

Other problems occur because of land conversion. For example, the land occupied by the Lorin Solo Hotel was once a productive rice field area. Around this hotel land, land use has also changed, for example being used as housing, restaurants and campuses. This means that the owners of the rice fields who used to work in the land as farmers have switched professions.

To win the competition in getting customers, the Hotel carries out various marketing efforts and other strategies. One of them is building an image through CSR activities.

In the perspective of environmental sustainability, clean water used by hotel customers must be efficient. The electrical energy used must also be economical. However, not many studies have been conducted to uncover hotel customers' perceptions of environmental preservation.

Hotels in Solo Raya have implemented CSR in the form of giving funds directly to the community. Activities carried out include school scholarships for children who live around the hotel, mass circumcision and so on. This activity is carried out in accordance with policies issued by the company and is incidental. Thus it can be seen that CSR carried out by hotels is still charity (Johny Subarkah, 2015).

The CSR activities of these hotels, especially Lorin, have been informed to customers and the public through the hotel internal news posted in the hotel lobby room and published through mass media with the slogan "From You Lorin Berbagi". So from this it builds a positive perception of the 
Vol-3, Issue-1, 2019 (IJEBAR)

ISSN: 2614-1280

http://www.jurnal.stie-aas/ijebar

customers of hotel guests. Based on the problems mentioned above, this study focuses on how the company's activities in community empowerment activities through corporate social responsibility have been carried out by hotels in Solo Raya, what are the keys to the success of these activities and how the company's empowerment model can be used as an example by other companies or institutions. So the author takes the title THE EFFECT OF CSR DEVELOPMENT IMPLEMENTATION ON MICRO BUSINESS POTENTIAL IN ENVIRONMENTAL CONSERVATION.

\section{STUDY OF LITERATURE}

\subsection{Corporate social responsibility}

Corporate social responsibility is defined as a business commitment to contribute to sustainable economic development, through collaboration with employees and representatives, families, local communities and the general public to improve the quality of life in ways that benefit both the business and the nation's development (Ambadar, 2008). The concept of Corporate Social Responsibility involves the responsibility of partnerships between government, community resource institutions, and local (local) communities. This partnership is not passive and static. This partnership is a social responsibility between stakeholders. The company reports its activities which include financial, managerial social accounting and social auditing (Harahap, 2004).

Article 33 paragraph (3) and (4) of the 1945 Constitution as the basis for the philosophy of natural resource management in Indonesia confirms that existing natural resources should be used as an effort to improve the welfare of society through development based on the principles of economic democracy. The company is no longer a selfish entity, alienation and / or exclusivity from the community environment, but a business entity that is obliged to carry out cultural adaptations to the social environment in which the company is located and is responsible for all damage and environmental impacts as a result of business activities which the company does. Research results (Gupta, 2003) most of the people in twenty-three countries gave high attention to the company's social behavior.

Elkington (1970) has stated the concept of CSR in three focus namely Profit, Planet and People or (3P), which is known as the triple bottom line. The synergy of these three elements is the key to the concept of sustainable development. CSR is a commitment of the business community to contribute to sustainable economic development in collaboration with labor, local communities and with the wider community, to improve the quality of life in ways that benefit both sides (Sripambudi, 2005).

Suparlan (2005) states that there is a general assumption that if a company or corporation has given a gift or monthly honorarium to local community leaders who are considered to have mastered and represented the community, then a variety of social and political problems that may arise from the local community will be faced and will harm the company. Community empowerment as part of implementing corporate social responsibility has a strategic position for a corporation, because corporations have the potential and capacity to implement community development programs (Suparlan, 2005).

Business strategy in CSR has a common understanding with the concept of social marketing (social marketing). According to Susanto (1990), social marketing is a design, implementation, and control of programs that have been calculated to influence the acceptance of social ideas and include considerations 
regarding product design, aspects of price, communication, and marketing research.

The role of the company in dealing with issues that have a dramatic impact on aspects of the environment and society around the company and on the future of the world, such as climate change or global warning, lack of water, education, information technology and poverty, economics, social and local culture (Schwab, 2008).

The basis of the concept of corporate citizenship is the implementation of CSR that is tailored to the context of the rights and obligations in which the company operates, where the basis of the implementation of corporate citizenship activities is part of CSR that is carried out simultaneously with company compliance with the laws and regulations where the company operates by implementing legal responsibilities (Carroll, 1991).

Logsdon and Wood (2005) propose the global concept of business citizenship and differentiate it from the concept of corporate citizenship which is dominated by philanthropic activities and community development programs. The pattern of corporate generosity that has been implemented so far has been quite good. The thing that needs to be improved is in the program of activities needed by the community in a short time such as education, health, economy, environment and community institutional strengthening.

The basic principles of social responsibility according to ISO 26000 which are the basis of implementation that animates or becomes information in making decisions and social responsibility activities include 1) compliance with the law; 2) respect for instruments / international bodies; 3) respect stakeholders and their interests; 4) accountability; 5) transparency; 6) ethical behavior; 7) take preventive measures; 8) respect the basics of human rights. While the definition of social responsibility is as follows:

Community empowerment can also be interpreted as 1) advisory work; 2) vulgarization or explanation / notification as it is (Roling, 1983) and 3) mobilization, imitation and awareness (Freire, 1973). As agents of information dissemination, empowerment must not only wait for the flow of information from sources of information (researchers, information centers, government institutions, media, and companies) but must actively hunt for information that is useful and or needed by the people who are their clients. In this relationship, empowerment must optimize the use of all available resources and all media / information channels that can be used such as newspapers, radio, television, mass media, banners and the internet so that they are not left behind and are still believed to be "new" information sources by the community.

Implementers of community empowerment must be active in filtering information provided or obtained by their clients from other sources, both concerning policies, products, methods, behavioral values and public perceptions. This is important, because in addition to empowerment activities, communities often also obtain information and innovations from other sources both from government officials, producers / business people, mass media, non-governmental organizations, universities that are not always "right" and useful / benefit the community. Therefore, experience shows, information that comes from "outside" is often more oriented to "outside interests" and there may be many hidden interests compared to its alignments to the interests of the people who are their clients (Mardikanto, 2010).

The implementation of community empowerment by companies needs to pay more attention to information from the community itself both in the form of 
"traditional wisdom" and "independent technology". This is important, because information originating from within, besides being tested by time, is often also more in line with local conditions, both in terms of technical, economic, social / cultural conditions, and conformity with the needs of local community development (Mardikanto, 2009) .

\subsection{Community Empowerment}

Community development is one way of approach that must be the standard principle for all government and nongovernment institutions and companies in carrying out their duties and functions in providing social services (Ambaddar, 2008). Meanwhile, according to Giarci (2001), it helps communities at various ages to grow and develop through various facilitation and support in order to be able to decide, plan and take action to manage and develop the biological, physical and social welfare environment. Soedjatmoko (1983) emphasizes motivation, goals, and meanings in the process of self-renewal in community development, and not merely material prosperity. So that conclusions on community development are actions in helping people to overcome all limitations.

Community development is all processes of change that are carried out through conscious and well-planned and sustainable efforts Riyadi and Supriyadi Bratakusumah, (2005). Whereas according to Siagian (1983), as a change, to realize a state of living and societal conditions that is better than current conditions, increasing the ability of a group to continue to develop, both qualitatively and quantitatively.

The concept of community empowerment has colored the community development paradigm. At the level of state life, community empowerment is interpreted as equal participation between governments, companies and communities (Syahyuti, 2006). All parties have the same responsibility in achieving goals. Community empowerment as a way to know, understand, understand, be motivated, have the opportunity to see opportunities, energize, be able to work together, know various alternatives, be able to take risks, be able to find and capture information (Slamet, 2000), and are not only the government's responsibility, but also companies and communities (Saputro, 2001).

Community empowerment as a process has five dimensions, namely 1) Enabling namely creating an atmosphere or climate that enables the potential of the community to develop optimally; 2) Empowering, namely strengthening the knowledge and capabilities of the community in solving problems and fulfilling their needs; 3) Protecting which is protecting the community, especially weak groups so as not to be oppressed by strong and dominant groups, avoiding unbalanced competition, preventing the exploitation of strong groups against the weak; 4) Supporting the provision of guidance and support to weak communities to be able to carry out their roles and functions of life; 5) Fostering is to maintain conducive conditions so that the balance of power distribution continues between various groups of people (Suharto, 1985).

Empowerment basically helps individuals, groups or communities try to control the lives of their own people and strive to shape the future as desired by society (Adi, 2003). According to Ife (1995), community empowerment contains two key understandings, namely power and weak groups.

Community empowerment by companies is now growing rapidly in Indonesia with various modes of organization. With increasing attention to its application, it marks the era of community awakening so that corporate empowerment should not only emphasize the philantropy 
aspect (humanitarian encouragement that comes from universal norms and ethics to help others and fight for social equality) and strategy level, but must be expanded further broader and more tangible forms of community empowerment (Korhenen, 2006).

The research results of Mardikanto (2003) have identified 3 (three) groups of community empowerment beneficiaries consisting of; 1) the main group, which consists of the community and their families; 2) determinant groups, which consist of decision makers about community empowerment policies; and 3) support groups, namely other community empowerment stakeholders, who directly or indirectly play a role in empowerment, all of which are involved in empowerment systems, both those that operate in the onfarm, off-farm and non-farm systems.

\section{METHODOLOGY}

\subsection{Place and Time}

The research location was established in Surakarta and Bali, which is a region that has a large number of hotels in Indonesia.

\subsection{Types of Research}

This research is designed quantitatively which is explanatory study and correlational. This study was not conducted intervention and control of variables such as normative ones carried out in an experimental study. This step was taken solely because of consideration of limited time, funds and infrastructure that supported the research. The terrorist model testing is done by analyzing the relationship of influence between variables in the model, through statistical testing of the hypothesis based on the results of the field research. While the sample was determined by group randomization in many stages.

\subsection{Populations and Samples}

The research population was all customers related to CSR activities of hotels in the former Surakarta residency in Central Java (Solo Raya) of 3 hotels /

Data sourced from hotel customers will be taken from 3 star hotels with a population of 1,900 taken by 331 respondents.

In the respondents of Farmers Micro Business, sample selection was done by purposive sampling. The following are the sample selection criteria:

1) Micro Farmer Business is the third partner of the hotel.

2) The duration of the partnership with the Hotel is at least 1 year.

The research data comes from primary data. First, primary data obtained from the distribution of questionnaires to hotel customers to measure variable customer perceptions, customer participation, implementation of government regulations and the development of CSR. Second, primary data obtained from content analysis on the results of interviews with Farmers Micro Enterprises to measure the variable empowerment of Micro Farmers in environmental conservation.

\subsection{Collection Techniques and Data Instruments}

1) Initial Data Collection

Initial data collection was conducted to test the measuring instruments before they were distributed to respondents who were the actual samples in this study. In addition, the initial data collection provided input regarding the constructs in this study.

\section{2) Preparation of the Preliminary \\ Questionnaire}

The next stage is the preparation of the questionnaire. At the beginning of the preparation of the questionnaire a pre-test 
Vol-3, Issue-1, 2019 (IJEBAR)

ISSN: 2614-1280

http://www.jurnal.stie-aas/ijebar

was carried out to obtain a valid and representative questionnaire for the next research phase.

\section{3) Distribution of the Initial Questionnaire}

The initial questionnaire was distributed to respondents who had the same characteristics as prospective respondents in the study sample. The aim is that the answers from respondents cannot be with the answers from the sample who are actually respondents.

\section{4) Testing the Research Questionnaire}

Testing the research measuring instrument aims to test the quality of valid and reliable measuring instruments to measure the variables to be measured in the study. Quality testing of measuring instruments used validity test and reliability test.

\section{a. Validity test}

Validity test is used to test the instrument so as to produce results in accordance with its objectives. Validity indicates the level of ability of the research instrument to measure what is desired and can reveal data and variables that are precisely examined (Singarimbun and Effendi, 1995). Validity testing is done by item analysis. An instrument is said to be valid, if the correlation coefficient is $\geq 0.113$ with $\alpha=0.05$. (Sugiyono, 2001).

\section{b. Reliability Test}

Reliability testing leads to the stability of a measuring instrument, where the level of reliability takes into account the extent to which a measuring instrument can be relied on and trusted (Singarimbun and Effendi, 1995). If a measuring device is used twice to measure the same symptoms and the measurement results obtained are relatively consistent, then the measuring device is reliable. In other words, reliability shows the consistency of a measuring device in measuring the same device. The reliability test of this research instrument produces alpha that has been standardized (standarized alpha item) and this alpha value must be greater than the allowable realiability associated with the number of questions in the questionnaire.

Efforts to improve instrument reliability, especially in the process of preparing and developing instruments and when we use these instruments to filter data. Instrument reliability test was carried out by looking at Cronbach's Alpha coefficient, and if $\alpha>0.5$, the research instrument was said to be reliable. Researchers use the SPSS 23 computer program to help speed up and make calculations easier.

\section{5) Interviews with Micro Farmers}

Interviews will be conducted on Farmers micro business actors in terms of environmental conservation. This interview was conducted to evaluate the application of the empowerment of Farmers Micro Enterprises by the Hotel. The results of the interview will be analyzed based on content analysis in getting the ratio of the level of empowerment of Micro Farmers in environmental conservation.

Measurement of field observation variables for primary data of a varibele is known to be an indicator and a method of measurement has been determined, then the method of measurement is in the form of numbers. These measurements are presented in the table below.

It can be explained that, if the company discloses an item it will be given a score of 1 , whereas if the item specified is not disclosed it will be given a score of 0 . Furthermore, a score of 1 is added together and divided by the maximum number of items that can be disclosed and multiplied by $100 \%$. 


\subsection{Data Analysis Techniques}

Path analysis techniques can help researchers determine whether the relationship between variable variables occurs directly or through intermediate variables and can also compare the size of the influence, both directly and indirectly. The steps to calculate the path coefficient are as follows:

\section{1) Make a path diagram}

Direct influence between variables from image path diagram (Chun, 1983 and Solimun, 2002). To find the indirect effect between variables sought by multiplying the path coefficient $(\beta)$.

Model 1. X2 $=\rho_{\mathrm{y} 2 \mathrm{y} 1} \mathrm{X} 1+\varepsilon_{2}$
Based on the frame of mind three models can be identified and four hypotheses will be tested as follows:

- Model 1: Y1: F (X1, X2). Hypothesis: H1 and $\mathrm{H} 2$

- Model 2: Y2 = F (Y1). Hypothesis: H3

- Model 3: Z = F (Y2). Hypothesis: H4

Next, to test the four proposed hypotheses, the framework is translated into the path analysis format. The results are obtained in the image below. Figure 1 is called a path diagram, the structural equation is formulated as follows:

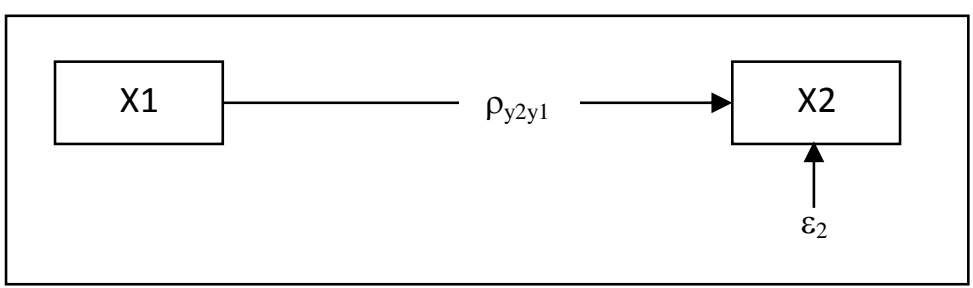

Figure 1

Path Diagram 1

The influence decomposition between variables explains the separation of total influence into a component of direct and indirect influence. In the path analysis format, the general form of decomposition of influences between variables in simultaneous equations according to Figure 2 can be seen in Table 3 .

\section{2) Hypothesis Testing}

Gujarati (1999) explains that to carry out standardized multiple linear regression testing that has a direct effect, it is used, $t$ test (individual test). The $t$ test is used to test the level of influence partially exogenous variables on endogenous variables.

If the calculation results show the results of $\mathrm{T}$-count $>\mathrm{T}$-table, then $\mathrm{H} 0$ is rejected or Ha is accepted. This means that partially the exogenous variables significantly influence the endogenous variables at the error rate $\alpha=0.05$ or compare the $\mathrm{P}$ value (significant) with the magnitude of the error rate $\alpha=0.05$. If $\mathrm{P}$ value is $<\alpha$, then $\mathrm{H}_{0}$ is rejected or $\mathrm{Ha}$ is accepted. It means that partially exogenous variables have a significant effect on endogenous variables at an error rate of 0.05 or $5 \%$.

\section{3) Model Validation Test}

Model validity test is used to test whether the path model used is appropriate or appropriate, by looking at the differences in correlation coefficients between path models with path coefficients $<0.05$, it can be assumed that the path model is used correctly. But on the contrary if the 
Vol-3, Issue-1, 2019 (IJEBAR)

ISSN: 2614-1280

http://www.jurnal.stie-aas/ijebar

difference in the value of the path coefficients $>0.05$, it can be assumed that the path model (path model) is not properly used or some path paths are not used (Sudjana, 2001).

\section{Measurement and Instrument Grid}

Measurement of field observation variables for primary data of a varibele is known to be an indicator and a method of measurement has been determined, then the method of measurement is in the form of numbers. These measurements are presented in the table below.

It can be explained that, if the company discloses an item it will be given a score of 1 , whereas if the item specified is not disclosed it will be given a score of 0 . Furthermore, a score of 1 is added together and divided by the maximum number of items that can be disclosed and multiplied by $100 \%$.

\section{RESEARCH RESULTS AND DISCUSSION}

\subsection{Variable CSR Development}

The CSR Development variables in this study are described in two aspects, namely environment and social. Environmental aspects are measured through 4 (four) indicators, namely Knowing the development of hotel CSR program funding for micro-businesses from year to year, Knowing the allocation of funds for hotel CSR programs for microbusinesses from year to year, Knowing the development of goods for hotel CSR programs for businesses micro from year to year, Knowing the development of knowledge provision for micro businesses from year to year, Knowing the development of the amount of material / environmental themes related to activities carried out by micro businesses from the year and Knowing the development of reducing waste formation at the source, specifically sourced from laundry / laundry.

\subsection{Variables of Micro Smallholder Enterprise Empowerment in Environmental Conservation}

The variable Micro Smallholder Enterprise Empowerment in Environmental Conservation is described in 8 indicators.

Data was obtained from 13 resource persons interviewed in depth during the period of December 2018. By analyzing the content of the answers to the sources, the following results were obtained:

\section{1). Mechanism of Accessing Business Sources}

Most business sources get capital from the owners themselves. To run a business, the company recruits daily employees to carry out the cultivation process with a management system that is controlled by the company manager. Goods or products in the form of fresh vegetables are sent directly to the hotel every morning.

2). Mechanism of Making and Maintaining a Business Network

Company leaders and owners establish communication with the hotel through an offer letter followed up by telephone communication. And to maintain a periodic relationship business owners meet directly with the hotel management to directly hear complaints from the hotel.

\section{3). Mechanism of Viewing Market Trends}

Take the time to talk and listen to what the customer feels, each customer has their own uniqueness. Not just print media, electronics to online media can be a valuable info mine for some business people. But what needs to be considered in using internet media is that it must be clever to separate which information really has the 
basis of assessing a trend and which is just a fake trend info. The last step is to summarize all the data that has been obtained. The recommendations that have been obtained can be recorded and then compare the two. From there the actual market trend will begin to be read. The more complex the recommendations are obtained, the better the results will be.

\section{4). The Search for Breakthrough Mechanism} for Choosing a Business

Choosing the type of business that is relatively small in competition, especially for Micro Farmers who are newly established. Many business opportunities are low competition but must be keen to capture these opportunities. Choose a brilliant business / business idea. The risk of UMP business failure will be small if the business idea is truly brilliant. It really knows what is needed by the community and knows how to fulfill it. Not hesitant, focused, acting without stopping and full of determination. Dare and don't stop acting, try and always correct mistakes. Manage resources as best as possible. Direct all existing resources towards the intended UMP goals.

\section{5). Mechanism of Attracting Customers}

An important factor in other marketing strategies is the issue of site selection. Identifying your target market will help you in developing an effective marketing strategy. Make promotional efforts or introduce your business products to consumers. Try to make the promotion that you do is consistent, continuous, and in creative ways so that customers don't feel bored. Get to know your customers. choose a strategic location. Use internet marketing. Internet marketing can be one of the most effective marketing strategies. relationship with customers.

6). Responding to Experiences That Make Convenience in Trading
Most UMP in addressing experiences that make comfort in trading by always maintaining good relationships with customers. Smooth communication and mutual trust are standard stances for most UMPs.

7). Choosing the Right Solution to Overcome It

Choosing the right solution to overcome problems in trying as follows: Mastering Problems, Finding and Finding Solutions, Choosing Decisions, Making Targets and Implementing Decisions, Making Evaluations.

8). Reference is used to anticipate inconvenience

To anticipate inconvenience, based on the answers of informants, it can be stated, among others, that the UMP evaluates what makes the inconvenience occur. Furthermore, after finding the cause, a solution is sought.

\subsection{Testing of Hypotheses}

The fourth hypothesis in this study is that it is suspected that the Development of CSR Hotels has a positive effect on the Empowerment of Farmers Micro Enterprises in Environmental Conservation.

Based on the results of hypothesis testing it can be seen that the Development of Hotel CSR has a significant influence on the Empowerment of Farmers Micro Enterprises in Environmental Conservation with a p-value of 0.02850 .05 , with a coefficient of 0.039 . Thus the fourth hypothesis which states that the Development of CSR Hotels has a positive effect on Micro Smallholder Enterprise Empowerment in Environmental Conservation is accepted. These results indicate that the Development of Hotel CSR has an impact on the Empowerment of Farmers Micro Enterprises in Environmental Conservation. 
Vol-3, Issue-1, 2019 (IJEBAR)

ISSN: 2614-1280

http://www.jurnal.stie-aas/ijebar

\subsection{Effects of CSR Development on Micro- Business Empowerment in Environmental Conservation}

The indicators in this study refer to the opinion of Slamet, (2000) and Saputro (2001) where community empowerment is a way to know, understand, understand, be motivated, have the opportunity to see opportunities, energize, be able to work together, know alternatives, be able to take risks, be able seeking and capturing information (Slamet, 2000), and not only the responsibility of the government, but also the company and the community (Saputro, 2001).

The results of the analysis revealed that customer participation had an effect on Micro Business Empowerment in Environmental Conservation. These results indicate that Micro Business Empowerment in Environmental Conservation is carried out depending on customer participation owned by the organization in this case the hotel.

\section{CONCLUSION}

1) The concept of CSR that can be applied to companies implementing community empowerment by companies has been developed in the approach that the basic concepts used by companies have a three bottom line concept, namely profit, people and planet, where this concept is still used as the basis for implementing corporate CSR. The integration of the planet, people and profits is inseparable and is a step that the company takes into account and takes responsibility for all company activities.

2) Development of CSR Hotels has a significant positive effect on the Empowerment of Farmers Micro Enterprises in Environmental Conservation
3) Factors that are able to build the empowerment of smallholder micro enterprises in environmental conservation through hotel CSR activities include customer perceptions, implementation of policies related to CSR and customer participation.

\section{REFERENCE}

Badaruddin, 2008. Implementation of Corporate Social Responsibility Towards Communities Through the Use of Potential Social Capital: Alternative Empowerment of the Poor in Indonesia, USU, Medan.

Brilliant, Eleanor L. and Kimberlee A. Rice. 1988. "Influencing Corporate Philanthropy" in Gary M. Gould and Michael L. Smith (eds), Social Work in the Workplace, New York: Springer Publishing Co.

Clarkson, M. 1995. A stakeholder framework for analyzing and evaluating corporate social performance. Academy of Management Review. Vol.20, pp.92117.

Chairil N. Siregar: Sociological Analysis of CSR Implementation in Indonesian Communities

Chotib, 2008, Sustainable Local Empowerment Model Through CSR Programs, News Demographics FE UI, Jakarta.

Devina, Florence, Suryanto, L and Zulaikha. 2004. Effect of Company Characteristics on Social Disclosures in the Go Public Company Annual Report on the Jakarta Stock Exchange (JSX). Maksi Journal. Volume 4. August: 161-177. 
Vol-3, Issue-1, 2019 (IJEBAR)

ISSN: 2614-1280

http://www.jurnal.stie-aas/ijebar

Elkington, J. 1997. Cannibals with Forks: The Triple Bottom Line of 21st Century Business, Capstone, Oxford.

Gunawan S, 2003. Community Empowerment and Social Safety Nets. Jakarta. PT Gramedia Main Library.

Ife, Jim 1995, Community Development: Creating Community Alternatives, Vision, Analysis and Practice, Longman, Australia.

Jahja SR, 2006. Evaluation of the Implementation of the Extractive Company Corporate Social Responsibility Activities. Galang Journal. Vol 2 No.1 of 2006. Jakarta.Pirac.

Kotler, Philip, and Nancy Lee, 2005. Corporate Social Responsibility: Doing the Most Good for Your Company and Your Cause, Hoboken, New Jersey: John Wiley and Sons, Inc.

Kotler, Lee. 2005. Corporate Social Responsibility: Doing The Most Good For Your Company and Your Cause. New Jersey: John Willey \& Sons.

Mahamed Zaini, 2008. Perpectives Social Responsibility and Impact on Society Management Center. University of Boardford. Volume 1. number 3. 2000. pp.172-178. ISSN 0954-4781.

Maskuri Untoro, 2010. Customer Satisfaction Stay at Starred Hotels in the Special Region of Yogyakarta, Strategic Journal, Volume 9, Number 17, February.

Morgan, Yufen Fu. "The Relationship between Corporate Social Responsibility and Earnings Response Coefficient: Evidence from Indonesian Stock Exchange". Department of
Ekonomics, Simon Fraser University, 8888 University Dr., Burnaby BC V5A 1S6: Faculty of Business Administration.

Marten.J.H., Et al., 2007. Corporate Social Responsibility of Multinational Companies to Local Communities: Case Study, Usahawan No. 03. Year. XXXVI, p. 9-18.

Mas'oed, 1993. Political Economy of Development and Community Empowerment. In Prospective Vol. 5 No.2 (1993).

Mardikanto.T. 1993. Extension of Agricultural Development. Surakarta: Eleven March University.

Mardikanto.T. 2004, "Social Welfare Problems and Social Work in Indonesia: Trends and Issues" (Social Welfare Problems and Social Work in Indonesia: Trends and Issues), paper presented at International Seminar on Social Work Education Curriculum Development in Indonesia, Bandung: School High Social Welfare.

Mardikanto.T. 2010. Concepts of Community Empowerment. Eleven March University Press - Surakarta.

Pamadi Wibowo, 2008. Stakeholders; Relationship Identification and Strategy. CSR. Workshop Serie 1. Jakarta. Indonesian CSR.

Peter Dreier, 1996. Community Empowerment Strategies: The Limit and Potential of Community Organizing In Urban Neighborhoods. Department of Housing and Urban Deveoplent. United States of America. Cityscape: A Journal of Policy Development and Research. Volume 2, Number 2. May. 
Ramanathan, K.V., 1976, Towards a theory of corporate social accounting, Accounting Review, Vol. LL No. 3, 518-528.

Saidi, Abidin. 2003. Corporate Social Contributions, Profiles and Patterns of Distribution in Indonesia: Survey of 226 Companies in 10 Cities by PIRAC. Jakarta: Ford Foundation.

Saidi., Zaim., And Hamid Abidin., 2004. Become a Gracious Nation: Discourse and Practice of Social Generosity in Indonesia, Jakarta: Pyramid.

Salim, E. (1993). Environmental Development. Jakarta: LP3ES

Santosa I. 2004. Empowerment of Forest Edge Farmers Through Adaptive Behavior Reform [dissertation]. Bogor: Bogor Agricultural Institute.

Sayekti, Yosefa and Wondabio, Ludovicus Sensi. 2007. "Effect of Disclosure CSR on Earning Response Coefficient". Makassar National X. Accounting Symposium, July 26-28

Slamet, R. Margono. 1990. Perspective of Development Counseling in the Era of Take-Off. Paper presented at the Seminar A Day on the Role of Development Counseling Towards the Era of Take-Off. September 25, 1990, Bogor Agricultural Institute (Bogor Agricultural University), Bogor, Indonesia.

Slamet, Y. 1993. Quantitative Analysis for Social Data. Solo: Dabara Publiseer.

Slamet M. 2003. Forming Patterns of Human Behavior Development. Bogor: IPB Press.

Susiloadi, Priyanto. 2008. "Implementation of Corporate Social Responsibility to
Support Sustainable Development." Public Spirit, Vol. 4, No. 2, h. . 123130. Accessed 